\title{
Relationship between Viral Load and Hepatic Histopathology in Patients with Chronic Hepatitis B
}

\author{
Kronik Hepatit B Tanılı Hastalarda Viral Yük ile Karaciğer Histopatolojisi Illișkisi
}

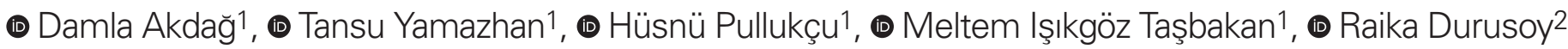 \\ 1Ege University Faculty of Medicine, Department of Infectious Diseases and Clinical Microbiology, Izmir, Turkey \\ ${ }^{2}$ Ege University Faculty of Medicine, Department of Public Health, Izmir, Turkey
}

\begin{abstract}
Objectives: It is not always possible to determine a clear relationship between the DNA level of hepatitis B virus (HBV) and histology. In this study, we aimed to determine the relationship between HBV-DNA level and liver histopathology in patients with chronic hepatitis.

Materials and Methods: Between 2008 and 2016, 361 patients diagnosed with chronic HBV infection were retrospectively examined with age, sex, hepatitis B e antigen status, alanine aminotransferase (ALT) and HBV-DNA levels and liver biopsy scores according to modified Ishak criteria. Patients were divided into five groups $\left(10^{5}, 10^{5}-10^{6}, 10^{6}-10^{7}, 10^{7}-10^{8}, \geq 10^{8}\right)$ based on their HBV-DNA level (IU/mL) and upon histopathological evaluation, hepatic injury was divided into two groups - mild and moderate/severe- according to Ishak score (grade 1-6: mild, 7-18: moderate/severe and stage 0-2: mild, 3-6: moderate/severe) to investigate the statistical relationship between HBVDNA levels and grade/stage scores. Cross-table and Pearson's chi-square test were used in the analyses.

Results: Of the three hundred and sixty-one patients, 62.3\% (225/361) were male and the average age was $40.32 \pm 12.79$. Anti-HBe (296/361) was positive in $82 \%$ of the patients, ALT, HBV-DNA averages were $83.17 \mathrm{U} / \mathrm{L}$ $( \pm 125.1), 57298951.01 \mathrm{IU} / \mathrm{mL}$ during biopsy, and grade and stage averages were 5.34 and 1.76 respectively. HBV-DNA groups with the grade's 2-binary groups when compared to moderate/high group, respectively, HBV-DNA $<10^{5}$ and $17.2 \%, 10^{5}-10^{6} 37 \%, 10^{6}-10^{7} \%$ in $46.9,107-10^{8} \%$ and 48.6 and 35.1 in $\geq 108$ were found. The difference between the groups was found to be statistically significant $(p<0.000)$. Similarly, HBV-DNA groups when compared to stage-binary groups, in the middle/high group, respectively, HBV-DNA $17.2 \%$ in $<105,32.6 \%$ in $10^{5}-10^{6}, 51 \%$ in $10^{6}-10^{7}, 48.6 \%$ in $10^{7}-$ $10^{8}$ and $35.1 \%$ in $\geq 10^{8}$ group were found and all of them were statistically significant $(p<0.000)$.

Conclusion: A HBV-DNA level was not found to be a threshold determining moderate/severe histopathological level. However, in group analysis, the histopathological relationship with the DNA level is directly proportional. Liver histology is an important marker determining the progression of the disease. Keywords: Viral hepatitis, hepatitis B, histopathology, viral
\end{abstract}

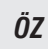

Amaç: Hepatit B virüs (HBV)-DNA düzeyi ile histoloji arasında her zaman net bir ilișki saptamak mümkün olmamaktadır. Bu çalıșmada kronik hepatit tanılı hastalarda HBV-DNA düzeyi ile karaciğer histopatolojisi arasındaki ilişkinin ortaya konması amaçlanmıştır.

Gereç ve Yöntemler: 2008-2016 yılları arasında kronik hepatit B tanılı 361 hastanın; yaș, cinsiyet, hepatit B e antijeni durumu, alanin aminotransferaz (ALT) ve HBV-DNA düzeyleri ile modifiye Ishak kriterlerine göre karaciğer biyopsi skorları retrospektif olarak incelenmiștir. HBV-DNA düzeyi ile grade/stage skorları arasındaki istatistiksel ilişkinin araștırılması açıından hastalar, HBV-DNA düzeyine göre 5 gruba $\left(<10^{5}\right.$, $\left.10^{5}-10^{6}, 10^{6}-10^{7}, 10^{7}-10^{8}, \geq 10^{8}\right)$, histopatolojik değerlendirmede ise grade: 1-6 hafif, 7-18 orta/yüksek; stage 1-2 hafif, 3-6 orta/yüksek olmak üzere olmak üzere 2'şerli gruplara ayrılmıştır. Analizlerde çapraz tablo ve Pearson'un ki-kare testi kullanılmıștır.

Bulgular: Üç yüz altmış bir hastanın \%62,3'si (225/361) erkek olup yaș ortalaması 40,32 $\pm 12,79$ idi. Hastaların \%82'sinin anti-HBe'si (296/361) pozitif olup, biyopsi esnasındaki ALT, HBV-DNA ortalamaları sırasıyla; $83,17 \mathrm{U} / \mathrm{L}( \pm 125,1) ; 57298951,01 \mathrm{IU} / \mathrm{mL}$ saptanmış olup, grade ve stage ortalamaları sırasıyla; 5,34 ve 1,76 olarak bulunmuştur. HBV-DNA ve grade'nin ikili grupları karşılaştırılı̆ğında orta yüksek grupta sırasıyla HBVDNA $<105$ iken $\% 17,2,10^{5}-10^{6^{\prime}}$ de $\% 37,10^{6}-10^{7}$ de $\% 46,9,10^{7}-10^{8^{\prime}}$ de $\% 48,6$ ve $\geq 10^{8}$ olan grupta $\% 35,1$ olarak tespit edilmiştir ve gruplar arasındaki fark istatistiksel olarak anlamlı bulunmuştur $(p<0,000)$. Aynı şekilde HBV-DNA grupları ile stage ikili grupları karşılaştııılığında orta yüksek grupta sırasıyla HBV-DNA $<10^{5}$ iken $\% 17,2,10^{5}-10^{6}$ de $\% 32,6$, $10^{6}-10^{7}$ de $\% 51,10^{7}-10^{8}$ de $\% 48,6$ ve $\geq 10^{8}$ olan grupta $\% 35,1^{\prime}$ dir ve gruplar arasındaki fark istatistiksel olarak anlamlı bulunmuştur $(p<0,000)$. Sonuç: Orta/ileri histopatolojik düzeyi belirleyen eşik bir HBV-DNA düzeyi bulunamamıştır. Ancak grupsal analizde DNA düzeyi ile histopatolojik ilişki doğru orantıııır. Kronik HBV tanıı hastalarda karaciğer histolojisi, hastalığın progresyonu belirleyen önemli bir belirteçtir.

Anahtar Kelimeler: Viral hepatit, hepatit B, histopatoloji, viral yük

Akdağ D, Yamazhan T, Pullukçu H, Işıkgöz Taşbakan M, Durusoy R. Relationship between Viral Load and Hepatic Histopathology in Patients with Chronic Hepatitis B. Viral Hepat J. 2020;26:1-4.

Address for Correspondence: Damla Akdağ MD, Ege University Faculty of Medicine, Department of Infectious Diseases and Clinical Microbiology, Izmir, Turkey Phone: +90 5556252118 E-mail: akdagdamla@hotmail.com ORCID ID: orcid.org/0000-0003-1700-7578 Received: 02.11.2019 Accepted: 19.12.2019

${ }^{\circ}$ Copyright 2020 by Viral Hepatitis Society / Viral Hepatitis Journal published by Galenos Publishing House. 


\section{Introduction}

Chronic hepatitis B virus (HBV) infections that are still commonly seen in our country are responsible for approximately one million deaths each year due to their fatal complications such as cirrhosis, hepatocellular carcinoma, and liver failure (1). A substantial proportion of these complications can be prevented with anti-viral therapy. Serum HBV-DNA levels and the level of hepatic necroinflammation and fibrosis are the two current criteria employed in the decision-making process to start antiviral treatment. In general, as the viral load increases, an evident deterioration in hepatic histology is expected, however at which HBV-DNA levels this histological degradation is predominant is not clear. This study aimed to statistically establish the relationship between HBV-DNA level and hepatic histopathology in patients who were diagnosed with chronic hepatitis and planned to start treatment and to find a HBV-DNA level which could be a reference point to determine the extent of moderate or advanced histopathological damage $(2,3)$.

\section{Materials and Methods}

This study retrospectively examined the biopsy results of 361 patients diagnosed with chronic HBV infection between 2008 and 2016 and who underwent liver biopsy to initiate treatment. The age, gender, hepatitis B e antigen ( $\mathrm{HBeAg}$ ) status, alanine aminotransferase (ALT) and HBV-DNA (RealArt HBV-polymerase chain reaction (PCR), Abbott, USA) levels of patients were evaluated compared with Ishak liver biopsy scores (4). Patients were divided into five groups $\left(<10^{5}, 10^{5}-10^{6}, 10^{6}-10^{7}, 10^{7}-10^{8}, \geq 10^{8}\right)$ based on their HBV-DNA level (IU/mL). Upon histopathological evaluation, hepatic injury was divided into two groups - mild and moderate/ severe- according to Ishak score. Based on this, the first threequarters (1-6) of the necroinflammatory activity, which is graded from 0 to 18 points, were classified as mild, and 7 and above (7-18) were classified as moderate/severe. Likewise, the scoring used to grade fibrosis from 0 to 6 points was divided into two groups where 0-2 points were classified as mild, 3-6 points were classified as moderate/severe fibrosis.

\section{Statistical Analysis}

A Spearman correlation analysis was conducted to explore a possible association between HBV-DNA and grade and stage as unclassified, continuous variables. A chi-square test and trend analysis was performed to compare the distribution of patients into the two grade and stage categories according to their classified HBV-DNA levels. Received operating characteristic curve analyses were performed to see if HBV-DNA as a continuous variable could be a good predictor of grade and stage classified into two categories. The HBV-DNA values of the naive and treatmentexperienced groups were compared using Mann-Whitney $U$ test. P values below 0.05 were considered statistically significant.

\section{Results}

Among the 361 participants, 62.3\% (225/361) were male with mean age being $40.32( \pm 12.79)$. Among the patients, $82 \%$ were anti-HBe-positive (296/361), 345 (95.6\%) were naive and 16 (4.4\%) were treatment-experienced. ALT, HBV-DNA means and grade and stage means of patients during biopsy are presented in Table 1.

Patients' distributions in binary groups (mild and moderate/ severe) by their necroenflammatory activity and fibrosis status when they are divided into 5 groups $\left(<10^{5}, 10^{5}-10^{6}, 10^{6}-10^{7}, 10^{7}-\right.$ $\left.10^{8},>=10^{8}\right)$ based on their HBV-DNA $(I \mathrm{U} / \mathrm{mL})$ levels are presented in Table 2.

There was a moderate, positive correlation between the HBVDNA values and grades of the patients $\left(r_{S}=0.344, p<0.0005\right)$ and a weak, positive correlation between their HBV-DNA values and their stages $\left(r_{s}=0.257, p<0.0005\right)$.

\begin{tabular}{|l|l|}
\hline \multicolumn{2}{|l|}{ Table 1. } \\
\hline Sex & $225(62.3 \%)$ \\
\hline Male & $136(37.7 \%)$ \\
\hline Female & $40.3 \pm 12.8$ \\
\hline Age & $65(18.0 \%)$ \\
\hline HBeAg & $296(82.0 \%)$ \\
\hline Positive & $83.17 \pm 125.1$ (median 52) \\
\hline Negative & 57.298 .951 (median 110.901) \\
\hline ALT(U/L) & $345(95.6 \%)$ \\
\hline HBV-DNA (IU/mL) & $16(4.4 \%)$ \\
\hline Treatment & \multicolumn{2}{|l|}{} \\
\hline Naive & $\begin{array}{l}5.3 \pm 2.6 \text { (minimum: 0, maximum: } \\
17, \text { median 5) }\end{array}$ \\
\hline Experienced & $\begin{array}{l}1.8 \pm 1.5 \text { (minimum: 0, maximum: 6, } \\
\text { median 2) }\end{array}$ \\
\hline Ishak & \begin{tabular}{l}
$\mid l$ \\
\hline Grade
\end{tabular} \\
\hline Stage & $\begin{array}{l}\text { HBeAg: Hepatitis B e antigen, ALT: Alanine aminotransferase HBV: Hepatitis } \\
\text { B virus }\end{array}$
\end{tabular}

Table 2. Grade and Stage Distributions by HBV-DNA levels ( $n$, percent to total)

\begin{tabular}{|l|l|l|l|l|}
\hline & \multicolumn{3}{|l|}{ Grade $(\mathbf{p}<\mathbf{0 . 0 0 5 )}$} & \multicolumn{3}{l|}{ Stage $(\mathbf{p}<0.0005)$} \\
\hline HBV-DNA & Mild & Moderate/Severe & Mild & Moderate/Severe \\
\hline$<10^{5}$ & $144(82.8)$ & $30(17.2)$ & $144(82.8)$ & $30(17.2)$ \\
\hline $10^{5}-<10^{6}$ & $29(63.0)$ & $17(37.0)$ & $31(67.4)$ & $15(32.6)$ \\
\hline $10^{6}-<10^{7}$ & $26(53.1)$ & $23(46.9)$ & $24(49.0)$ & $25(51.0)$ \\
\hline $10^{7}-10^{8}$ & $18(51.4)$ & $17(48.6)$ & $18(51.4)$ & $17(48.6)$ \\
\hline $10^{8}$ and higher & $37(64.9)$ & $20(35.1)$ & $37(64.9)$ & $20(35.1)$ \\
\hline Total & $254(70.4)$ & $107(29.6)$ & $254(70.4)$ & $107(29.6)$ \\
\hline HBV: Hepatitis B virus & & & & \\
\hline
\end{tabular}


There was a statistically significant difference among grade groups compared to DNA level groups. As HBV-DNA levels increased, the proportion of patients in the moderate/severe group increased, which was statistically significant ( $p<0.0005$, Table 2).

Similarly, there was a statistically significant difference between distributions by HBV-DNA level and by Stage with an increasing trend $(\mathrm{p}<0.0005$, Table 2).

There was no significant difference between the mean HBVDNA values of the naive and treatment-experienced groups $(U=2108.5, p=0.110)$.

The area under the curve of HBV-DNA to predict grade 2-3 was 0.65 , while it was 0.63 for predicting stage (Figure $1 \mathrm{a}$ and $1 \mathrm{~b}$ ). For example if $\mathrm{HBV}$-DNA is cut from $10^{5}$, its sensitivity to predict grade becomes $72.0 \%$ and specificity $66.7 \%$ while if it is cut from $10^{6}$, its sensitivity to predict grade becomes $56.1 \%$ and specificity $68.1 \%$. Similarly, if HBV-DNA is cut from $10^{5}$, its sensitivity to predict stage becomes $72.0 \%$ and specificity $66.7 \%$ while if it is cut from $10^{6}$, its sensitivity to predict stage becomes $57.9 \%$ and specificity $68.9 \%$.

\section{Discussion}

In addition to ALT elevation, HBV-DNA level and the extent of liver damage are two criteria that are employed in the decisionmaking process to initiate antiviral treatment for chronic HBV infection.

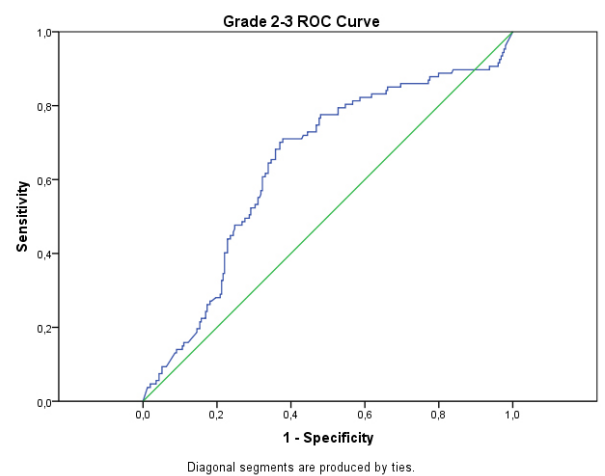

Figure 1a. Receiver operating characteristic curve of hepatitis B virusDNA in predicting Grade 2-3

ROC: Receiver operating characteristic

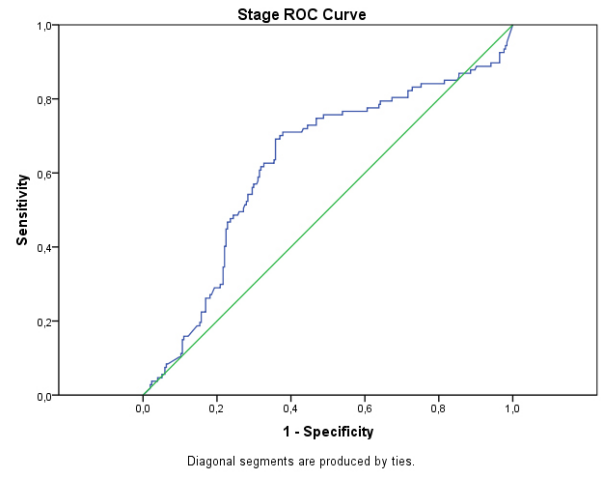

Figure 1b. Receiver operating characteristic curve of hepatitis B virus DNA in predicting stage

ROC: Receiver operating characteristic
National and international guidelines emphasized the importance of HBV-DNA level to determine the threshold to initiate treatment, and standardization was attempted to establish in this regard with no consensus being reached at the end. In the guideline updated by Asian Pacific Association for the Study of the Liver in 2016, treatment initiation threshold were defined as 2000 $\mathrm{IU} / \mathrm{mL}$ and above for HBV-DNA for cirrhotic patient groups who have ALT level within normal ranges and non-cirrhotic patients groups who are HBeAg-negative (5). In the guideline published by the European Association for the Study of the Liver in 2017, the treatment limit was set at $2000 \mathrm{IU} / \mathrm{mL}$ and treatment was recommended to be initiated in patients with HBV-DNA above $20.000 \mathrm{IU} / \mathrm{mL}$ and who had elevated ALT, regardless of fibrosis level$^{2}$. World Health Organization stated in its guideline that treatment should be initiated regardless of $\mathrm{HBeAg}$ status if HBVDNA level is $>20.000 \mathrm{lU} / \mathrm{mL}$ in non-cirrhotic patients with elevated ALT levels over 30 years of age (6).

This study attempted to find a threshold level range for HBVDNA at which hepatic damage began in patients that were divided into 5 groups based on a $\log ^{10}$ increase of serum HBV-DNA levels between $10.000\left(10^{5}\right)$ and $100.000 .000\left(10^{8}\right)$. The aim of finding a highly sensitive and specific threshold HBV-DNA level to predict moderate/advanced liver damage which would be an indication for treatment could not be achieved in the statistical analysis. Low HBV-DNA levels in patients with mild liver damage, although statistically significant, were already expected (7). Unexpectedly, only in the last group, ie., in the group with HBV-DNA level higher than $10^{8}$, the number of patients with low grade and stage was found to be higher than in the previous subgroup $\left(10^{7}-10^{8}\right)$. This can be explained by the presence of, although in small numbers, immunotolerant patients in this group.

Similar studies have shown that serum HBV-DNA correlates with necroinflammation and fibrosis, and that as the levels of HBVDNA increase, the risk of cirrhosis significantly increases. In a study published by lloeje et al. (8) in 2006, 365 out of 3582 patients with chronic hepatitis $B$ were diagnosed with cirrhosis in 11 years of follow-up and the incidence of cirrhosis was found to be $4.5 \%$ in patients with hepatitis B viral load less than 300 copies $/ \mathrm{mL}$ and $36.2 \%$ in patients with hepatitis B viral load more than 106 copies/ $\mathrm{mL}(\mathrm{p}<0.001)$. In a study by Nabuco et al. (9) conducted for similar purposes in 78 blood donors who were HBsAg-positive, HBV-DNA levels were significantly higher in patients with chronic hepatitis or cirrhosis compared with patients without histologic hepatic disease, although histologic lesions were mild in the majority of patients (25.260.000 vs 9480 copies/mL; $p<0.001$ ). There was also a significant correlation between HBV-DNA levels and necroinflammatory score $(r=0.59)$ and fibrosis $(r=0.50)$. However, $25 \%$ of the subgroup (of HBeAg-negative patients) with HBV-DNA levels less than 30.000 copies $/ \mathrm{mL}$ was reported to have HBVrelated histologic disease.

Similarly, there are many studies showing a significant relationship between HBV levels and risk for hepatocellular carcinoma, and these studies emphasize the relationship between the level of HBV-DNA and the severity of the histological lesion in the course of HBV infection $(10,11)$. In the study by Chen et al. (10), the incidence rate of hepatocellular carcinoma was $1.3 \%$ when HBV-DNA level was 300 copies $/ \mathrm{mL}$ and lower vs. 
14.9\% when HBV-DNA level was one million copies $/ \mathrm{mL}$ and above. However, there are also studies showing that there is no correlation with the extent of hepatic necro-inflammatory activity or fibrosis in patients with chronic HBV infection, and that some patients have progressive liver disease although HBV-DNA levels are undetectable and ALT levels are consistently within normal ranges (12).

Determination of hepatic histology by liver biopsy in patients with chronic hepatitis B is an important predictor of disease progression. However, in recent years, the avoidance of invasive methods such as liver biopsy, alternatively employing non-invasive techniques such as serum fibrotic markers or fibroscans have been proposed in the guidelines as well (2). The most important noninvasive method leading the diagnostic and therapeutic methods used in chronic hepatitis B infection is the measurement of HBVDNA level. With the introduction of sensitive molecular diagnostic tests, particularly PCR based on amplification of the target working principle, HBV-DNA was measured at detectable levels in the majority of individuals with chronic HBV infection, including those who were inactive carriers (13). These results give rise to important questions regarding the relationship of HBV-DNA levels measured by non-invasive methods with hepatic histopathology of patients diagnosed with clinically significant and chronic HBV infection.

\section{Study Limitations}

Although a correlation was found between viral load level and histopathology in our study, a sensitive and specific cut-off value could not be determined. One of the reasons for this is that there is no history of viral load, necroinflammation and fibrosis grouping in the literature, therefore they were performed subjectively. In addition, subgroup analysis was not performed based on patients HBeAg status, ALT levels, age and history of alcohol use. Therefore, we think that statistically significant results can be obtained from advanced studies with subgroup analyzes performed and a different grouping method employed.

\section{Conclusion}

No threshold HBV-DNA level was found to determine the moderate/severe histopathological level. However, in group analysis, the histopathological relationship with DNA level were proportional. Liver histology in patients with chronic hepatitis B is an important predictor of disease progression.

\section{Ethics}

Ethics Committee Approval: This study was approved by Ege University Faculty of Medicine, Department of Infectious Diseases and Clinical Microbiology (approval number: 60770832, date:15.01.2016).

Informed Consent: Since our study was retrospective, informed consent was not used.

Peer-review: Externally peer-reviewed.

\section{Authorship Contributions}

Surgical and Medical Practices: D.A., T.Y., H.P., M.T., Concept: D.A., T.Y., H.P., M.T., Design: D.A., T.Y., H.P., M.T., Data Collection or Processing: D.A., Analysis or Interpretation: D.A., T.Y., R.D., Literature Search: D.A., T.Y., Writing: D.A., T.Y.
Conflict of Interest: Authors declare no conflict of interest. Financial Disclosure: There was no aid and sponsor for this study.

\section{References}

1. World Health Organization Hepatitis B Fact sheet $\mathrm{N}^{\circ} 204$. Updated July 2015 Available from: URL: http://www.who.int/mediacentre/ factsheets/fs204_Jul2014/en/

2. European Association for the Study of the Liver. EASL 2017 Clinical Practice Guidelines on the Management of hepatitis B virus Infection. Journal of Hepatology. 2017;67:370-398.

3. Shao J, Wei L, Wang H, Sun Y, Zhang LF, Li J, Dong JQ. Relationship between hepatitis $B$ virus DNA levels and liver histology in patients with chronic hepatitis B. World J Gastroenterol. 2007;13:21042107.

4. Ishak K, Baptista A, Bianchi L, Callea F, De Grootes J, Gudat F, Denk H, Desmet V, Korb G, MacSweeni RNM, Phillips MJ, Portmann BG, Paulsen $H$, Scheuer PJ, Schmid M, Thaler $H$. Histological grading and staging of chronic hepatitis. J Hepatol. 1995:22:696-699.

5. Sarin SK, Kumar M, Lau GK, Abbas Z, Chan HL, Chen CJ, Chen DS, Chen HL, Chen PJ, Chien RN, Dokmeci AK, Gane E, Hou JL, Jafri W, Jia J, Kim JH, Lai CL, Lee HC, Lim SG, Liu CJ, Locarnini S, Al Mahtab M, Mohamed R, Omata M, Park J, Piratvisuth T, Sharma BC, Sollano J, Wang FS, Wei L, Yuen MF, Zheng SS, Kao $\mathrm{JH}$. Asian-Pacific clinical practice guidelines on the management of hepatitis B: a 2015 update. Hepatol Int. 2016;10:1-98.

6. World Health Organization, Guidelines for the Prevention, Care and Treatment of Persons with Chronic Hepatitis B Infection. 2015 Mar

7. Lindh $M$, Horal P, Dhillon AP, Norkrans G. Hepatitis B virus DNA levels, precore mutations, genotypes and histological activity in chronic hepatitis B. J Viral Hepat. 2000;7:258-267.

8. Iloeje UH, Yang HI, Su J, Jen CL, You SL, Chen CJ, Risk Evaluation of Viral Load Elevation and Associated Liver Disease/CancerIn HBV (the REVEAL-HBV) Study Group. Predicting cirrhosis risk based on the level of circulating hepatitis $B$ viral load. Gastroenterology. 2006;130:678-686.

9. Nabuco LC, Villela-Nogueira CA, Perez RM, Ceci L, Pannain VL, Nogueira CM, Segadas-Soares JA, Coelho HS. HBV-DNA Levels in HBsAg-positive Blood Donors and its Relationship With Liver Histology. Journal of Clinical Gastroenterology. 2007.

10. Chen CJ, Yang HI, Su J, Jen CL, You SL, Lu SN, Huang GT, Iloeje UH; REVEAL-HBV Study Group. Risk of hepatocellular carcinoma across a biological gradient of serum hepatitis B virus DNA level. JAMA. 2006;295:65-73.

11. Yang HI, Lu SN, Liaw YF, You SL, Sun CA, Wang LY, Hsiao CK, Chen PJ, Chen DS, Chen CJ; Taiwan Community-Based Cancer Screening Project Group. Hepatitis B e antigen and the risk of hepatocellular carcinoma. N Engl J Med. 2002;347:168-174.

12. Mahtab MA, Rahman S, Khan M, Kamal M, Mamun AA, Karim MF Viral load speaks little about toll on liver. Hepatobiliary Pancreat Dis Int. 2007;6:483-486.

13. Loriot MA, Marcellin P, Bismuth E, Martinot-Peignoux M, Boyer N, Degott $C$, Erlinger S, Benhamou JP. Demonstration of hepatitis B virus DNA by polymerase chain reaction in the serum and the liver after spontaneous or therapeutically induced $\mathrm{HBeAg}$ to anti-HBe or HBsAg to anti-HBs serum conversion in patients with chronic hepatitis B. Hepatology. 1992;15:32-36. 